\title{
Long-Tailed Macaques (Macaca fascicularis) and Humans Interactions in Grojogan Sewu Natural Park (TWA GS), Karanganyar Regency, Central Java Province
}

\author{
Moh. Jafron Syah \\ ${ }^{1}$ Study Program of Animal Biosciences, Department of Biology, Faculty of Mathematics and Natural \\ Sciences, Bogor Agricultural University. Darmaga Bogor, 16680, West Java, Indonesia \\ E-mail:jafronsyah@gmail.com
}

\begin{abstract}
Macaca fascicularis is one species of primate that easily adapts to various habitats, such as disturbances habitat, like a natural park. The conflict between $M$. fascicularis and human increases due to changes in ecology. In Borneo, Sumatra, Malaysia, Mauritus, and Thailand, M. fascicularis has become pests because destroyed orchards and plantations. Interaction between M. fascicularis and human, which occurred at several natural parks in Singapura and Kaliurang caused by M. fascicularis's attraction to food brought by humans. This research aimed to study the interaction between M. fascicularis with the humans in Grojogan Sewu Natural Park (TWA GS) by direct observation and also an interview with visitors, workers, and villagers. Based on direct observation, frequency of affiliation interaction between humans and M. fascicularis (55.56\%) is higher than agonistic interaction (44.4\%). The dominant affiliation interaction was sitting nearby the visitors (42.96\%); meanwhile, the most dominant agonistic interaction was stealing (54.12\%) because the M. fascicularis attracted to food (67.02\%). Workers reported having more nuisance problem with $M$. fascicularis than visitors and villagers. Almost all of the respondents thought that $M$. fascicularis needs to be kept alive in the park, and consider conservation and protection of the macaques are essential.
\end{abstract}

Keywords: affiliation, agonistic, conservation, interaction, natural park

\section{Preface}

Macacca fascicularis (Family: Cercopithecidae) in Indonesia is known as longtailed monkeys. According to Wheatley (1980), $M$. fascicularis is a species of primates that are highly adaptive to a variety of habitat types. $M$. fascicularis can be found in both primary and secondary forest (Fooden 1995). This species can also be found in the forest canopy, forest river, coastal, mangrove, swamp, and forest tourism (Gumert et al. 2011; Fakhri et al. 2012).

The conflict between $M$. fascicularis and human currently increase due to the presence of ecological changes; one of the cases is a conflict between M. fascicularis and human in the natural park. Sha et al. (2009) reported some natural parks in Singapore did not have a buffer zone with the area of settlement. Around the Bukit Timah Natural Resource (BTNR), there are seven condos and one estate where is only 200 meters from the BTNR. These situations endorse conflict between M. fascicularis and human because M. Fascicularis can easily reach the human area.

As reported by Lee and Priston (2005), $M$. fascicularis was also one of the types of pests in different regions of such as Borneo, Malaysia,
Mauritus, Sumatra and Thailand because they damaged the orchards and plantations. Hambali et al. (2012) reported that $M$. fascicularis in the Nature Park in Kuala selangor, Malaysia entered the residential area and destroyed the facility residents.

Previous studies about interaction between $M$. fascicularis and human in the natural park showed that $M$. fascicularis stole things from human in some natural parks in Singapore and Kaliurang occurred because they are interested in the food brought by humans (Sha et al. 2009). Meanwhile, the biting interaction of $M$. fascicularis against humans in Padangtegal, Bali and Gibraltar occurred because humans interfered $M$. fascicularis (Fuentes et al. 2007).

Grojogan Sewu Natural Park (TWA GS) is one of the conservation areas in Tawangmangu Village, District Tawangmangu, Karanganyar Regency, Province of Central Java. TWA GS has a function as a conservation park, e.g. species $M$. fascicularis (Siswantoro et al. 2012). TWA GS does not have a buffer zone so that the interaction between $M$. fascicularis and citizens can not be avoided. 
There is no study found regarding the interaction between human and $M$. fascicularis in TWA GS. The results of this study can be used as a basis in conservation management of $M$. fascicularis in TWA GS. using ad libitum methods (Altman 1974). The type of interactions observed in this study refer to Sha et al. (2009) with some modifications. Interactions were classified into two: (1) aggressive interactions, consist of mobbing, lunging and chasing, threatening facial or vocal threats, stealing luggage, scratching, and bitting, and (2) affiliative gestures consist of proximity and physical contact without aggression.

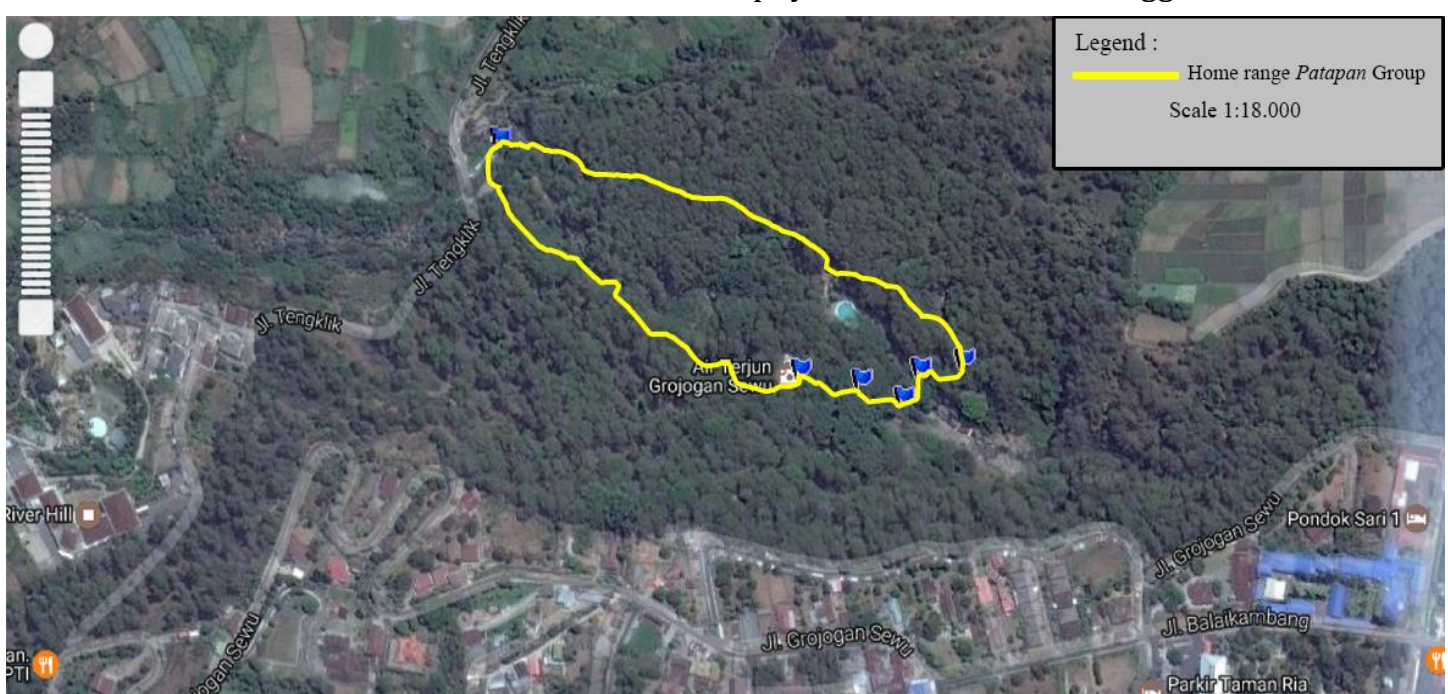

Figure 1. Research location and home range of patapan group long tailed macaques in TWA GS

\section{Materials and Methods \\ 2.1. Study Site}

This research was conducted in TWA GS, which is located in the administrative region of Karanganyar Regency, Province of Central Java. The location of TWA GS is on S 703917-703949 and E 401853 - 4²016 with altitude 950 meters above sea level. TWA GS has a total area of 64,30 hectares (Siswantoro et al. 2012). There are two groups of M. fascicularis inhabitant TWA GS, namely pandhapa and patapan. Home range of pandhapa group located near counter 1, meanwhile home range of patapan group located near waterfalls.

\subsection{Observation of Macaque to Human Interactions}

The observation of interactions between M. fascicularis and humans was conducted from August until November 2016. The group composition of $M$. fascicularis in TWA GS was calculated directly using concentration count (Rinaldi 1992). The interaction between $M$. fascicularis and humans was observed only in patapan group, because from early observation data, the frequency of interaction between $M$. fascicularis and humans in patapan group was higher compared to pandhapa group. The observation of interaction between $M$. fascicularis and humans was conducted six hours per day

\subsection{Questionnaire Survey}

The questionnaire survey included questions about opinions, knowledge, and attitudes of participants toward macaques in TWA GS (Table 1). Participants were divided into visitors $(n=222)$, workers $(n=54)$, and residents $(n=74)$. The visitors are tourists who visit in TWA GS. The workers are employees and seller in TWA GS. Residents were selected based on the distance between their homes and the TWA GS location. We choose distance less than $500 \mathrm{~m}$ because $M$. fascicularis can reach that area.

\subsection{Data Analysis}

Data about macaques-humans interactions and questionnaire survey were analyzed by descriptive.

\section{Results}

\subsection{Group Composition of Macaques in TWA} GS.

The patapan group consisted of 79 individuals with 18 adult males, 23 adult females, 33 juveniles, and five infants. 


\subsection{The Human and Patapan Group Interaction.}

The interactions of humans- macaques in patapan group were classified into agonistic and affiliation. The frequency of affiliation behaviour $(55.56 \%)$ was higher than agonistic behaviour (44.44\%). The most frequent affiliation behaviour was proximity $(42.96 \%)$ and then physical contact without aggression (12.60\%). Meanwhile, the most frequent agonistic behaviour was grabbing $(26.11 \%)$, followed by facial or vocal threats $(15.37 \%)$, lunging and chasing $(1.30 \%)$, scratching $(1.11 \%)$, bitting $(0.37 \%)$, and mobbing $(0.19 \%)$, respectively (table2). humans $(67.06 \%)$. The second to that was an aggressive gesture of human (16.47\%), macaques provoked by humans (10.59\%), and natural playfulness (5.88\%) (Table 3).

\subsubsection{Feeding Interactions.}

More than $50 \%$ of respondents stated that they did not feed macaques in TWA GS and will never do that in future. The visitors (59.46\%) and workers $(55.56 \%)$ stated that they did not feed macaques in TWA GS. Contrast to the residents' result that they did not feed macaques in TWA GS (47.30\%). Most of the respondents did

not agree with the feeding ban in TWA GS $(65.43 \%)$ due to insufficient natural food of

Table 1. Questions on this study

\begin{tabular}{cl}
\hline Number & \multicolumn{1}{c}{ Question } \\
\hline 1. & How is your attitude towards macaques in TWA GS? \\
2. & Have you ever had experienced nuisance problem with macaques in TWA GS? \\
3. & What type of problem experienced? \\
4. & What is the cause of problem? \\
5. & Have you ever fed monkey in past? \\
6. & Will you feed monkey in future? \\
7. & Is the natural food of macaque enough in TWA GS? \\
8. & Do you agree with effectiveness of feeding ban to macaques in TWA GS? \\
9. & How to manage the macaque problem in TWA GS? \\
10. & Is the conservation of macaques in TWA GS necessary to be applied? \\
\hline
\end{tabular}

\subsection{Interview Result}

\subsection{Human Reports on Interactions.}

As many as $48.57 \%$ of respondents were experiencing nuisance problem with macaques in TWA GS. The most common conflict experienced by visitors $(56.47 \%)$ and workers $(68.29 \%)$ were grabbed by the macaques. On the other hand, the residents experienced lunging and chasing by macaques $(45.45 \%)$. The main factor triggering the nuisance problem was due to many of macaques are interested in foods brought by macaques $(61.71 \%)$. The visitors $(61.26 \%)$ and residents $(81.08 \%)$ claimed that the natural food for Macaques di TWA GS was inadequate, but the workers claimed the opposite opinion (62.96\%).

\subsubsection{Attitudes About Macaques and Their Management.}

More than $50 \%$ of visitors and residents are fond of the presence of macaques. The same applied to $42.59 \%$ of workers there. Some of the visitors $(27.03 \%)$, workers $(42.59 \%)$ and residents (44.59\%) were neutral; meanwhile, a fraction of visitors $(8.56 \%)$, workers $(14.81 \%)$,

Table 2. The human and patapan group interactions in TWA GS

\begin{tabular}{lcc}
\hline Interaction & $\begin{array}{c}\text { Number of interaction } \\
\text { (N) }\end{array}$ & $\begin{array}{c}\text { Percentage } \\
\text { (\%) }\end{array}$ \\
\hline Affiliative gesture & $\mathbf{( 3 0 0 )}$ & $\mathbf{( 5 5 . 5 6 )}$ \\
Proximity & 232 & 42.96 \\
Physical contact without aggression & 68 & 12.60 \\
& & \\
Agonistic & $\mathbf{( 2 4 0 )}$ & $\mathbf{4 4 4 . 4 4 )}$ \\
Grabbing & 141 & 26.11 \\
Facial or vocal threats & 83 & 15.37 \\
Lunging and chasing & 7 & 1.30 \\
Scratching & 6 & 1.11 \\
Bitting & 2 & 0.37 \\
Mobbing & 1 & 0.19 \\
\hline Total & $\mathbf{5 4 0}$ & $\mathbf{1 0 0}$ \\
\hline
\end{tabular}


and residents (4.05\%) dislike macaques. Most of the respondents assumed that macaques in TWA GS need to be kept alive in the park (57.02\%) for educational purpose. Meanwhile, 22.06\% of respondents thought to keep away troubled

Table 3. Results of interviews with visitors, workers, and residents about their attitudes, opinions, and experiences of macaques in TWA GS

\begin{tabular}{|c|c|c|c|c|c|c|c|c|}
\hline \multirow[t]{2}{*}{ Questions } & \multicolumn{2}{|c|}{ Visitor } & \multicolumn{2}{|c|}{ Worker } & \multicolumn{2}{|c|}{ sidence } & \multicolumn{2}{|c|}{$\begin{array}{c}\text { Total ( Visitor + } \\
\text { Worker + } \\
\text { Residence) }\end{array}$} \\
\hline & $\mathrm{N}$ & $\%$ & $\mathrm{~N}$ & $\%$ & $\mathrm{~N}$ & $\%$ & $\mathrm{~N}$ & $\%$ \\
\hline \multicolumn{9}{|l|}{ Attitude towards M. fascicularis existence in TWA GS } \\
\hline Like & 143 & $64.41 \%$ & 23 & $42.59 \%$ & 38 & $51.35 \%$ & 204 & $58.29 \%$ \\
\hline Nuetral & 60 & $27.03 \%$ & 23 & $42.59 \%$ & 33 & $44.59 \%$ & 116 & $33.14 \%$ \\
\hline \multirow[t]{2}{*}{ Dislike } & 19 & $8.56 \%$ & 8 & $14.81 \%$ & 3 & $4.05 \%$ & 30 & $8.57 \%$ \\
\hline & 222 & & 54 & & 74 & & 350 & \\
\hline \multicolumn{9}{|l|}{ Have been in conflict with Macaques } \\
\hline Yes & 85 & $38.29 \%$ & 41 & $75.93 \%$ & 44 & $59.46 \%$ & 170 & $48.57 \%$ \\
\hline \multirow[t]{2}{*}{ No } & 137 & $61.71 \%$ & 13 & $24.07 \%$ & 30 & $40.54 \%$ & 180 & $51.43 \%$ \\
\hline & 222 & & 54 & & 74 & & 350 & \\
\hline \multicolumn{9}{|l|}{ Kind of conflict with Macaques in TWA GS } \\
\hline Grabbing & 48 & $56.47 \%$ & 28 & $68.29 \%$ & 16 & $36.36 \%$ & 92 & $54.12 \%$ \\
\hline Lunging and chasing & 29 & $34.12 \%$ & 10 & $24.39 \%$ & 20 & $45.45 \%$ & 59 & $34.71 \%$ \\
\hline Spoiling/ravaging stuff & 3 & $3.53 \%$ & 3 & $7.32 \%$ & 8 & $18.18 \%$ & 14 & $8.24 \%$ \\
\hline \multirow[t]{2}{*}{ Bitting } & 5 & $5.88 \%$ & 0 & 0 & 0 & 0 & 5 & $2.94 \%$ \\
\hline & 85 & & 41 & & 44 & & 170 & \\
\hline \multicolumn{9}{|l|}{ Cause of human-Macaques conflict in TWA GS } \\
\hline Natural palyfulness & 1 & $1.18 \%$ & 2 & $4.88 \%$ & 7 & $15.91 \%$ & 10 & $5.88 \%$ \\
\hline Macaques affected by human's behaviour & 12 & $14.12 \%$ & 3 & $7.32 \%$ & 3 & $6.82 \%$ & 18 & $10.59 \%$ \\
\hline Macaques does aggressive gesture & 19 & $22.35 \%$ & 3 & $7.32 \%$ & 6 & $13.64 \%$ & 28 & $16.47 \%$ \\
\hline \multirow[t]{2}{*}{ Macaques interested in foods } & 53 & $62.35 \%$ & 33 & $80.49 \%$ & 28 & $63.64 \%$ & 114 & $67.06 \%$ \\
\hline & 85 & & 41 & & 44 & & 170 & \\
\hline \multicolumn{9}{|l|}{ Feeding in the past } \\
\hline Yes & 90 & $40.54 \%$ & 24 & $44.44 \%$ & 39 & $52.70 \%$ & 153 & $43.71 \%$ \\
\hline \multirow[t]{2}{*}{ No } & 132 & $59.46 \%$ & 30 & $55.56 \%$ & 35 & $47.30 \%$ & 197 & $56.29 \%$ \\
\hline & 222 & & 54 & & 74 & & 350 & \\
\hline \multicolumn{9}{|l|}{ Feeding in the future } \\
\hline Yes & 79 & $35.59 \%$ & 19 & $35.19 \%$ & 34 & $45.95 \%$ & 132 & $37.71 \%$ \\
\hline \multirow[t]{2}{*}{ No } & 143 & $64.41 \%$ & 35 & $64.81 \%$ & 40 & $54.05 \%$ & 218 & $62.29 \%$ \\
\hline & 222 & & 54 & & 74 & & 350 & \\
\hline \multicolumn{9}{|l|}{ Natural food existence in TWA Grojogan Sewu } \\
\hline Sufficient & 86 & $38.74 \%$ & 34 & $62.96 \%$ & 14 & $18.92 \%$ & 134 & $38.29 \%$ \\
\hline \multirow[t]{2}{*}{ Insufficient } & 136 & $61.26 \%$ & 20 & $37.04 \%$ & 60 & $81.08 \%$ & 216 & $61.71 \%$ \\
\hline & 222 & & 54 & & 74 & & 350 & \\
\hline \multicolumn{9}{|l|}{ Handling method of troubled Macaques } \\
\hline Exterminate the troubled Macaques & 7 & $3.15 \%$ & 1 & $1.85 \%$ & 2 & $2.74 \%$ & 10 & $2.87 \%$ \\
\hline Let it be, as people education media & 133 & $59.91 \%$ & 31 & $57.41 \%$ & 35 & $47.95 \%$ & 199 & $57.02 \%$ \\
\hline Displace the troubling Macaques & 22 & $9.91 \%$ & 3 & $5.56 \%$ & 9 & $12.33 \%$ & 34 & $9.74 \%$ \\
\hline Decreasing the number of Macaques in TWA GS & 5 & $2.25 \%$ & 12 & $22.22 \%$ & 12 & $16.44 \%$ & 29 & $8.31 \%$ \\
\hline \multirow[t]{2}{*}{ Dissociate Macaques from village near TWA GS } & 55 & $24.77 \%$ & 7 & $12.96 \%$ & 15 & $20.55 \%$ & 77 & $22.06 \%$ \\
\hline & 222 & & 54 & & 73 & & 349 & \\
\hline Feeding prohibition of $M$. fascicularis & & & & & & & & \\
\hline
\end{tabular}

macaques from the urban area. A fraction of respondents (9.74\%) believed that the macaques need to be removed from TWA GS, reduce the number of macaques $(8.31 \%)$, and only $2.87 \%$ agreed to eradicate macaques. Most of the respondents agreed that the conservation efforts of macaques are essential to do in TWA GS (96.56\%) (Table 3).

\section{Discussion}

The frequency of affiliation interaction between M. fascicularis and human in TWA GS was higher than that of agonistic interaction. The result of this study is similar to those in Singapore and TWA Telaga Warna, Bogor (Sha et al. 2009; Hardin 2015). The highest affiliation interaction in TWA Telaga Warna was monkeys approaching human. In this study, the most observed of 
affiliation interaction was proximity where $M$. fascicularis sitting next to human and used as photo's object by visitors. The second highest affiliation interaction was physical contact without aggression, where visitors touch $M$. fascicularis.

The most frequent agonistic interaction in this study was when $M$. fascicularis grab things from the human. The macaque is also interested in food sold by the seller. The frequency of grabbing in TWA GS was higher than that in Singapore (18.15\%) and Botanical Garden Penang (BGP), Malaysia (18\%) (Sha et al. 2009; Perveen et al. 2014). The frequency of human bitten by $M$. fascicularis in TWA GS occurred only two occurences out of 240 observed agonistic interactions and happened when visitors fed or distracted M. fascicularis. In Padangtegal Wenara Warna, Bali, 48 of bitten cases from 420 interaction were observed (Fuentes et al. 2007), in Gibraltar, there was 39 bitten interaction found (Fuentes 2006), while in Singapore seemed no bitten interaction occurred (Sha et al. 2009).

The result from actual observation towards human-M. fascicularis interaction in TWA GS was linear to the result of the interview. About $50 \%$ of respondents were reported to have a conflict with $M$. fascicularis. The highest conflict was grabbing, followed by lunged and chased by $M$. fascicularis. This interactions were caused by $M$. fascicularis who frequently interested in human's stuff. $M$. fascicularis followed the visitors who brought a bag or food in a plastic bag. This result was similar to what has been happened in Singapore (Sha et al. 2009) and TWA Kuala Selangor, Malaysia (Hambali et al. 2012).

Based on the interview result, the visitors and workers tended not to give any food to $M$. fascicularis. On the other hand, the residents feed M. fascicularis. Visitors and workers are having more awareness about the danger posed by feeding $M$. fascicularis than residents. In Singapore, the percentage of respondents who feed $M$. fascicularis was lower $(14.2 \%)$ than in TWA GS. This condition is due to the fine system that has been applied in Singapore. The regulation in some tourist parks aimed to reduce the direct interaction between $M$. fascicularis and human, in order to prevent disease transmission from $M$. fascicularis to human. In TWA GS and Padangtegal Wenara Warna, Bali (Fuentes et al. 2007), the feeding ban has been enforced but without fine system. It makes people ignore the rule and still feed the M. fascicularis.

The results show that most respondents in this study were fond of the presence of $M$. fascicularis. The situation is different from Singapore, where most people showed neutrality with the presence of $M$. fascicularis (Sha et al.
2009). In this study, most respondents thought that $M$. fascicularis in TWA GS need to be kept alive because they can be used as primate edutourism. This positive attitude showed that respondent understood the importance of $M$. fascicularis conservation and can be served as a base for supporting $M$. fascicularis conservation effort (Rocha dan Fortes 2015).

Factors triggering agonistic interaction between $M$. fascicularis and human in TWA GS were mostly caused by the macaques interested in food and human disturbance. Some regulation needs to be applied to reduce agonistic interaction, such as prohibition for human of bringing foods and not disturbing $M$. fascicularis in the tourist area. The macaque- human interaction may also be caused by the lack of availability of $M$. fascicularis natural food source in TWA GS. It is crucial to do future research on the feeding ecology of $M$. fascicularis in TWA GS as an effort to deal with M. Fascicularis and human problem.

\section{Acknowledgements}

The author thanks BKSDA of Central Java who permitted this research.

\section{References}

Altman J. 1974. Observational Study of Behaviour: Sampling Methods. Chicago (US): University of Chicago.

Djuwantoko, Retno NU, Wiyono. 2008. Interaksi agresif monyet, Macaca fascicularis (Raffles, 1821) terhadap wisatawan di hutan wisata alam kaliurang, Yogyakarta. Biodiversitas. 9(4): 301-305.

Fakhri H. 2012. Studi awal populasi dan distribusi Macaca fascicularis di Cagar Alam Ulolanang Raffles. [skripsi]. Semarang (ID): Universitas Negeri Semarang.

Fooden J. 1995. Systematic review of Southeast Asian long tail macaques, Macaca fascicularis. Field Zool. New series (81): 1- 20.

Fuentes A. 2006. Human culture and monkey behaviour: assessing the context of potential pathogen transmission between macaques and humans. Am J Primatol. 68: 880- 896.

Fuentes A, Shaw E, Cortes J. 2007. Qualitative assessment of macaques tourist sites in Padangtegal Bali, Indonesia and the upper rock nature reserve, Gibraltar. Int J Primatol. 28: 11431158.

Gumert MD, Fuentes A, and Jones Engel L.2011. Monkey on The Edge: Ecology and Management of Long- Tailed Macaques and Their Interface with Humans. New York (US): Cambridge University Press. 
Hambali K, Ismail A, Zulkifli SZ, MD-Zain BM, Anuar A. 2012. Human- macaque conflict and pest behaviour of long tailed macaques (Macaca fascicularis) in Kuala Selangor Natural Park. TNH. 12(2): 189-205.

Hardin CM. 2015. Macaca fascicularis- human interaction in Telaga Warna, Bogor, West Java. [skripsi]. Bogor (ID): Institut Pertanian Bogor.

Lee PC, Priston NEC. 2005. Human Attitudes to Primates: Perceptions of Pests, Conflict and Consequences for Primate Conservation. In: Paterson JD, Wallis J, Editors. Commensalism and Conflict : The Human Primate Interface. Norman, Oklahama: American Society of Primatology. P: 123.

Perveen F, Karimullah, Anuar S. 2014. Longtailed macaques, Macaca fascicularis (primate: Cercopithecidae) : human-monkey behavioural interaction in Botanical Garden Penang, Malaysia. Annals Exp Biol. 2(1): 36-44.

Rinaldi D. 1992. The use of triangel and concentration count methods in the investigation of gibbon distribution and population. Media Konser. 4: 9-21.

Rocha LC, Fortes VB. 2015. Perceptions and attitudes of rural residents towards capuchin monkey, in the area of influence of the Dona Francisca Hydroelectric Power Plant, South Brazil. Amb n Soc. 18 (4): 19-34.

Sha JCM, Gumert MD, Lee BPYH, Engel LJ, Chan S, Fuentes A. 2009. Macaque- human interactions and the social perception of macaques in Singapore. Am J Primatol. 71: 825-839.

Siswantoro H, Sutrisno A, Dwi PS. 2012. Strategi optimasi wisata massal di kawasan konservasi taman wisata alam Grojogan Sewu. J Ilmu Lingk. 10 (2): 100-116.

Wheatley BP. 1980. Feeding and Ranging of East Bornean Macaca fascicularis. New York (US): Van Nostrand Reinhold co. pp:215-246. 